GRADIATION\&APPLICATIONS

ISSN 2466-4294 (online) | rad-journal.org

Vol. 2 | Issue 3 | pp. 226 - 229, 2017

doi: 10.21175/RadJ.2017.03.045

Original research paper

\title{
ELASTOGRAPHY AND SHEAR WAVE ELASTOMETRY-BASED VALUES OF YOUNG'S MODULUS OF ENDOMETRIUM IN HEALTHY WOMEN OF REPRODUCTIVE AGE*
}

\author{
V.N. Diomidova1,2*** O.V. Zakharova1,3 \\ ${ }^{1}$ I. N. Ulyanov Chuvash State University, Cheboksary, Russia \\ ${ }^{2}$ City Clinical Hospital №1, Cheboksary, Russia \\ 3First I. M. Sechenov Moscow State Medical University, Moscow, Russia
}

\begin{abstract}
The analysis of the data of uterus examination of 45 healthy women of reproductive age was carried out; 22 of the patients were practically healthy nulliparous women, 23 of the patients were healthy parous women (1 or 2 children). The age of the patients ranged from 24 to 48 years of age (mean age $33.9 \pm 2.9$ years). A comprehensive ultrasound examination of the uterus and appendages with the use of ultrasound elastography and shear wave elastometry modes (SWE - Shear Wave Elastography) was carried out on the unit Aixplorer (Supersonic Imagine, France) using a convex abdominal transducer with the frequency range of 1.o-6.o $\mathrm{MHz}$ and intracavitary vaginal broadband probe of 3-12 MHz. SWE results in the control group showed that the quantitative values of Young's modulus of unmodified endometrium and myometrium in healthy women of reproductive age were not potentially dependant on various phases of menstrual cycle ( $\rho>0.05$ ). Young's modulus values of the mucous in the cervix (endocervix) and uterus corpus (endometrium) differed significantly and in healthy women had greater values in the cervix (Emean $33.1 \mathrm{kPa}$; Emax $38.8 \mathrm{kPa} ; \mathrm{SD}$ 1.9) rather than in the corpus of uterus (Emean $16.5 \mathrm{kPa}$; Emax 17.6 kPa; $S D$ 1.o; $\rho<0.05)$. Depending on the parity, healthy parous women had higher values of endometrium stiffness Emean $17.5 \mathrm{kPa}$; Emax $35.5 \mathrm{kPa}$; SD 3.1 than nulliparous women - $16.1 \mathrm{kPa}$; $19.9 \mathrm{kPa}$; o.7 $(\rho<0.05)$. Quantitative values of Young's modulus of the myometrium in healthy patients were also higher in the cervix rather than in the corpus of uterus (Emean $42.3 \mathrm{kPa}$; Emax $52.4 \mathrm{kPa}$; SD 3.2 and Emean $22.3 \mathrm{kPa}$; Emax $29.3 \mathrm{kPa}$; SD 1.7; $\rho<0.05$ respectively). In the examination of women of reproductive age that was carried out on the basis of the data obtained from the use of elastography and shear wave elastometry technology, standard values for Young's modulus for an unmodified endometrium, endocervicx, myometrium of the uterus corpus and cervix in healthy women of reproductive age were defined.
\end{abstract}

Key words: Elastometry, endometrium, shear wave elastography, ultrasound diagnostics

\section{INTRODUCTION}

The clinical examination algorithm for women having pathology of the uterus and its adnexa has considerably improved with the introduction of Doppler technologies using transvaginal access [1]. In recent years, opportunities of ultrasonic diagnostics have significantly increased due to the use of a new technology - ultrasonic elastography, allowing to qualitatively and quantitatively measure mechanical properties of various soft-tissue structures, musculoskeletal system, glandular and parenchymatous organs [2] - [4].

Shear wave elastography confidently enters into clinical practice of hepatology, mammology, thyrology, urology, oncology, pediatrics, as it allows us to evaluate the non-invasively rigidity of investigated structures [5] - [8]. A continuously growing number of publications concerning research results in recent years have enabled elastography and shear wave elastometry to pass from being an experimental method into the category of fairly used clinical methods [9], [10].

The main argument in favor of using elastography with shear wave elastometry in practical health care has been the introduction of the given technology to the clinical practice with a view to expanding the diagnostic spectrum and getting additional opportunities to influence the decision made in difficult diagnostic situations [10]. For example, it has been established that the determination of the rigidity of quantitative values is highly informative in breast cancer diagnosis (Young's modulus threshold value of $55.3 \mathrm{kPa}$ is characterized by the sensitivity of $97.7 \%$, and specificity of $85.9 \%$ ) [8].

Studies on the use of shear wave elastography in diagnostics of gynecological pathology are very few [11] - [16]. Among them, there is a study of Mit'kov et al. [13] which estimates Young's modulus values of myometrium at adenomyosis (when examining

\footnotetext{
* The paper was presented at the Fifth International Conference on Radiation and Applications in Various Fields of Research (RAD 2017), Budva, Montenegro, 2017.

*diomidovavn@rambler.ru
} 
V.N. Diomidova, O.V. Zakharova, Elastography and shear wave elastometry-based values..., Rad. Applic., 2017, 2, 3, 226-229

patients with suspected adenomyosis, Young's modulus threshold value of $35 \mathrm{kPa}$ is characterized by $92.2 \%$ sensitivity and $95.0 \%$ specificity) (Aixplorer, SuperSonic Imagine, France).

In another study of Mit'kov et al. [12], values of Young's modulus for uterine body myometrium in reproductive age women (the median Emean - 24.6 $\mathrm{kPa}$, Emax - $29.4 \mathrm{kPa})$ and postmenopausal age women (Emean - $16.9 \mathrm{kPa}$, Emax - $20.1 \mathrm{kPa}$ ) are significantly different (Aixplorer, SuperSonic Imagine). Young's modulus values in an unchanged myometrium are also noted not to depend on a woman's menstrual cycle phase [12].

Interestingly, the shear wave elastography method is characterized by good reproducibility when examining gynecological organs and it does not require extra time for studies [11].

In an experimental study of Carlson et al. [15], it is shown that shear wave speed values rise from distal to proximal cervical parts $(\mathrm{P}<0.0001)$, (S2000, Siemens, Germany).

Hernandez-Andrade et al. [16] in their work compared shear wave speed in the field of external and internal os at different depths (Aixplorer, SuperSonic Imagine, France). Quantification was carried out in cervical cross section in anterior, lateral, posterior parts as well as in the field of endocervix. 154 pregnant women at $11-36$ weeks of gestation were surveyed. In the internal os area, shear wave speed of endocervix was significantly lower compared with other localizations only later than 14 weeks of gestation. In the external os area, shear wave speed in the anterior part and endocervix was significantly lower when compared to other localizations. As in the work of Carlson et al. [15], higher values of shear wave speed in the internal os area were received. In addition, Hernandez-Andrade et al. [16] in their work described significant inverse correlations in shear wave speed values and gestational age, typical for all localizations.

The purpose of our research is the development of Young's modulus standard values for endometrium in reproductive age women.

\section{STUDY MATERIALS AND METHODS}

The analysis of integrated uterine ultrasound examination data in 45 reproductive age women was carried out, among whom 22 were practically healthy nonparous women, 23 - practically healthy parous women ( 1 child or 2 children). The age of the surveyed ranged from 24 to 48 years.

The examination program included clinicalanamnestic and laboratory-instrumental diagnostics methods. Inclusion criteria in the study were: reproductive age of the patient; absence of gynecological, systemic and endocrine diseases, surgical interventions and caesarean sections in their past medical history and at the time of the study; absence of hormonal and other medicines taking; normal sonographic picture of the uterus and its adnexa; terms not earlier than 9 months after the last delivery and regular menstruation setting after childbirth not less than 3 months; and informed consent of the woman.

Ultrasound examinations of the uterus and its adnexa were carried out using Aixplorer (Supersonic Imagine, France) in different modes of ultrasound imaging using a convex transabdominal transducer with a frequency range of 1-6 $\mathrm{MHz}$ and an intracavitary transvaginal transducer with a frequency range of 3-12 $\mathrm{MHz}$.

A complex echographic examination of uterus and its adnexa consisted of several sequentially used echoscanning modes. According to a generally accepted standard technology, echography of the uterus and its adnexa was conducted in two-dimensional gray-scale and Doppler modes using standard analysis schema for normal and pathological gynecological organs with transabdominal and transvaginal accesses to evaluate the morphofunctional condition of the uterus and ovaries.

At the next stage, after compulsory urinary bladder emptying, patients had uterus examination performed with a transvaginal uterine transducer using the ultrasonic shear wave elastography mode. Passing to the elastography mode was carried out after obtaining an optimal ultrasound image of all structural uterine elements in gray-scale B-mode. To obtain a highquality elastography map, an ultrasonic sensor was installed without the compression on the organ being examined; only light pressure was applied of such force that it was necessary to obtain a clear picture of the organs in B-mode.

After the stabilization of the maximum dyed elastography map in the color window, we passed to the qualitative visual characteristic of the elastogram. In the window of interest, the quality of elastography map and predominant background color by appropriate color scale were assessed. We used the type of color elastography map at which more rigid structures were dyed into the red color, less rigid structures gave different shades of blue and intermediate rigidity tissues gave a yellow-green color.

Further, establishing the zone of interest (Q-box) in the uterine body and cervix area, a quantification of Young's modulus (rigidity) of the investigated part (not less than three areas of myometrium, endometrium and endocervix followed by averaging the data received) was performed. The size of the color window changed depending on the part being examined. When examining the myometrium, the Q-box diameter was installed at the level from 3 to $10 \mathrm{~mm}$, whereas during endometrium examination - at $2 \mathrm{~mm}$. At this, the measuring depth and Young's modulus value scale $(180 \mathrm{kPa})$ complied with the manufacturer's recommendations.

Then, the evaluation of the following quantitative characteristics of Young's modulus was carried out: average (Emean) and maximum (Emax) values and standard deviation (SD). The data obtained were processed using standard statistical methods in the form of the median (50 $\mathrm{O}^{\text {th }}$ percentile), $25-75^{\text {th }}$ and 2.5 - 97.5 $5^{\text {th }}$ percentiles, of the minimum and maximum values. At $\mathrm{P} \leq 0.05$, differences were considered to be significant. 


\section{RESEARCH RESULTS}

A visual qualitative assessment of elastograms by a corresponding color scale was made after a full staining of the window of interest in different parts of the uterus. The time needed for the stabilization of the color elastography map was about $4 \mathrm{sec}$. When using shear wave elastography, a uniformly stained homogeneous blue background (180 $\mathrm{kPa}$ scale) was determined in the color box both in the area of myometrium and endometrium (endocervix).

Young's modulus values obtained in the examination of healthy reproductive age women are presented in tables 1 and 2. Emean and Emax values in the area of endometrium and endocervix as well as the ones of uterine body and cervix myometrium were significantly different - higher values are typical for endocervix and uterine cervix myometrium, respectively.

Table 1. Young's modulus values for endometrium and endocervix in healthy reproductive age women $(n=45)$

\begin{tabular}{|c|c|c|c|}
\hline \multirow{2}{*}{ Uterine part } & \multicolumn{3}{|c|}{ Young's modulus, kPa } \\
\cline { 2 - 4 } & Emean & Emax & SD \\
\hline \multirow{3}{*}{ Body } & 16.5 & 17.6 & 1.0 \\
& $11.9-22.4$ & $13.6-24.1$ & $0.7-1.8$ \\
& $6.4-26.2$ & $8.5-30.3$ & $0.5-3.2$ \\
& $5.7-29.3$ & $7.7-33.7$ & $0.3-4.7$ \\
\hline \multirow{4}{*}{ Cervix } & $33.1^{*}$ & $38.8^{*}$ & 1.9 \\
& $25.0-41.1$ & $27.1-46.8$ & $0.9-3.2$ \\
& $21.3-44.6$ & $22.6-51.5$ & $0.6-4.8$ \\
& $17.2-49.7$ & $18.3-52.9$ & $0.2-5.2$ \\
\hline
\end{tabular}

Note. Here and further, the first line shows the median, the second $25-75^{\text {th }}$ percentiles, the third $-2.5-97.5^{\text {th }}$ percentiles, the fourth - the minimal-maximum values. * - significance of differences when comparing the rigidity of endometrium and endocervix at $\mathrm{P} \leq \mathrm{0.05}$.

Table 2. Young's modulus values for myometrium in the area of uterine body and cervix in healthy reproductive age women $(n=45)$

\begin{tabular}{|c|c|c|c|}
\hline \multirow{2}{*}{ Uterine part } & \multicolumn{3}{|c|}{ Young's modulus. kPa } \\
\cline { 2 - 4 } & Emean & Emax & SD \\
\hline \multirow{4}{*}{ Body } & 22.3 & 29.3 & 1.7 \\
& $17.0-33.2$ & $15.6-52.4$ & $1.3-8.5$ \\
& $8.4-40.5$ & $12.8-55.8$ & $0.9-9.6$ \\
& $7.0-41.8$ & $10.7-57.0$ & $0.3-10.6$ \\
\hline \multirow{4}{*}{ Cervix } & $42.3^{*}$ & $52.4^{*}$ & 3.2 \\
& $23.2-64.2$ & $25.8-74.7$ & $1.9-7.4$ \\
& $21.8-72.1$ & $23.3-87.4$ & $1.6-9.0$ \\
& $17.2-83.7$ & $22.6-99.5$ & $0.1-10.5$ \\
\hline
\end{tabular}

Note. Quantitative parameters are shown as in Table 1. * - significance of differences when comparing the rigidity of myometrium in different parts at $\mathrm{P} \leq 0.05$.

\section{CONCLUSION}

As it has already been mentioned above, in available literature, there are only individual publications on the results of application of shear wave elastography technology for evaluating the rigidity of various uterine parts. Thereby, some of them are performed ex vivo [14], [15]. In the work of Mit'kov et al. [12], rigidity normative values range $\left(2.5-97.5^{\text {th }}\right.$ percentiles) (Young's modulus) for uterine body myometrium in reproductive age women varies from
17.8 to $33.0 \mathrm{kPa}$ (the median is $24.6 \mathrm{kPa}$ ) for Emean, from 21.4 to $36.5 \mathrm{kPa}$ (the median is $29.4 \mathrm{kPa}$ ) for Emax. The results of our work are consistent with these data with greater variance in Young's modulus values $\left(2.5-97.5^{\text {th }}\right.$ percentiles for Emean $-8.4-40.5 \mathrm{kPa}$, for Emax - 12.8 - 55.8 $\mathrm{kPa}$ ).

However, in contrast to the research of HernandezAndrade et al. [16], who established that shear wave speed in endocervix was significantly lower compared with uterine cervix myometrium, in our work Young's modulus values for endocervix were higher compared with cervical myometrium. The same was found by us for uterine body endometrium and myometrium as well $(\mathrm{P} \leq 0.05)$. However, it should be noted that Hernandez-Andrade et al. [16] surveyed pregnant women at 11-36 weeks of gestation, and the internal os area shear wave speed of endocervix was significantly lower compared with cervical myometrium only after 14 weeks of gestation.

Thus, the study of healthy reproductive age women using the shear wave elastography technology established normative values of Young's modulus for unmodified endometrium, endocervix, uterine cervix and body myometrium, which can be used for practical application in differential diagnosis of various uterine pathologies. The clinical significance of the given technology should be evaluated in future studies of women with particular characteristics of various changes in the uterus.

\section{REFERENCES}

1. Е.В. Федорова, А.Д. Липман, А.И. Омельяненко, В.П. Шакунова, "Исследования маточного и яичникового кровотока у пациенток с бесплодием при лечении методами вспомогательных репродуктивных технологий. I. Исследование кровотока яичников, фолликула и желтого тела," Ультразвуковая и функциональная диагностика, но. 3, стр. 133 - 141, 2002. (Е. V. Fedorova, A. D. Lipman, A. I. Omelyanenko, V. P. Shakunova, "Study of uterine and ovarian blood flow in afetal patients when treating by subsidiary reproductive technologies. I. Study of blood flow in ovaries, follicle and yellow body," Ultrasound Funct. Diag., no. 3, pp. $133-141,2002$.)

2. Б. И. Зыкин, Н. А. Постнова, М. Е. Медведев, “Эластография: анатомия метода," Променева діагностика, променева терапія, но. 3, стр. 107 113, 2012. (B. I. Zykin, N. A. Postnova, M. E. Medvedev, "Elastography: anatomy of the method," Radiat. Diag. Radiat. Ther., no. 3, pp. $107-113,2012$.

Retrieved from:

https://rehamed.in.ua/images/Pdpt_2012_2-3_24.pdf Retrieved on: Jan. 28, 2017

3. В.В. Митьков, А.К. Васильева, М.Д. Митькова, "Механические (упругие) свойства предстательной железы при эластографии сдвиговой волны," Ультразвуковая и функциональная диагностика, но. 6, стр. 16 - 20, 2012. (V. V. Mit'kov, A. K. Vasil'eva, M. D. Mit'kova, "Mechanical (elastic) properties of the prostate gland at shear wave elastography," Ultrasound Funct. Diag., no. 6, pp. 16 - 20, 2012.)

4. В. В. Митьков, Т. В. Иванишина, М. Д. Митькова, "Ультразвуковое исследование неизмененной щитовидной железы с применением технологии эластографии сдвиговой волной,” Ультразвуковая и функциональная диагностика, но. 6, стр. 13 - 20, 
V.N. Diomidova, O.V. Zakharova, Elastography and shear wave elastometry-based values..., Rad. Applic., 2017, 2, 3, 226-229

2012. (V. V. Mit'kov, T. V. Ivanishina, M. D. Mit'kova, "Ultrasound examination of unchanged thyroid gland using shear wave elastography technique," Ultrasound Funct. Diag., no. 6, pp. 13 -20, 2014.)

5. В.Н.Диомидова, О. В. Петрова, “Сравнительный анализ результатов эластографии сдвиговой волной и транзиентной эластографии в диагностике диффузных заболеваний печени," Ультразвуковая и функциональная диагностика, но. 5, стр. 17 - 24, 2013. (V. N. Diomidova, O. V. Petrova, "Comparative results' analysis of shear wave elastography and transient elastography in diagnosis of diffuse liver diseases," Ultrasound Funct. Diag., no. 5, pp. 17 - 24, 2013.)

6. Б. И. Зыкин, Н. А. Постнова, “Значение цветового картирования жесткости печеночной ткани при проведении исследований с помощью эластографии сдвиговой волной у больных гепатитом С," Ультразвуковая и функциональная диагностика, но. 5, стр. 24 - 30, 2013. (B. I. Zykin, N. A. Postnova, "Significance of liver tissue rigidity color mapping when performing examination with shear wave elastography in hepatitis C patients," Ultrasound Funct. Diag., no. 5, pp. $24-30,2013$.)

7. Ю. В. Кабин, А. И. Громов, В. В. Капустин, "Первый опыт применения ультразвуковой эластографии сдвиговой волной в диагностике рака молочной железы," Ультразвуковая и функциональная диагностика, но. 5, стр. 79 - 84, 2013. (Yu. V. Kabin, A. I. Gromov, V. V. Kapustin, "Shear wave elastography in breast cancer diagnosis (first experience), Ultrasound Funct. Diag., no. 5, pp. $79-84$, 2013.)

8. В. В. Митьков, К. А. Чубарова, Н. В. Заболотская, М. Д. Митькова, Н. В. Яурова, “Информативность ультразвуковой эластографии сдвиговой волной в диагностике рака молочной железы," Ультразвуковая и функциональная диагностика, но. 1, стр. 11 - 24, 2014. (V. V. Mit'kov, K. A. Chubarova, N. V. Zabolotskaja, M. D. Mit'kova, N. V. Jaurova, "Informativity of ultrasound shear wave elastography in breast cancer diagnosis," Ultrasound Funct. Diag., no. 1, pp. $11-24,2014$.)

9. Е. В. Феоктистова, М. И. Пыков, А. А. Амосова, M. А. Тарасов, М. М. Дубровин, "Применение ARFIэластографии для оценки жесткости печени у детей различных возрастных групп," Ультразвуковая и функциональная диагностика, но. 6, стр. 46 - 56, 2013. (E. V. Feoktistova, M. I. Pykov, A. A. Amosova, M. A. Tarasov, M. M. Dubrovin, "Application of ARFIelastography to assess liver rigidity in children of different age groups," Ultrasound Funct. Diag., no. 6, pp. $46-56,2013$.)

10. Е. А. Вишленкова, Г. Т. Синюкова, Т. Ю. Данзанова, "Ультразвуковая эластометрия и эластография у пациентов с метастазами колоректального рака в печени на фоне химиотерапии перед операцией и в удаленном макропрепарате," Ультразвуковая u функциональная диагностика, но. 4, стр. 25 - 30,
2014. (E. A. Vishlenkova, G. T. Sinjukova T. Yu. Danzanova, "Ultrasound elastometry and elastography in patients with liver metastases of colorectal cancer during chemotherapy before the surgery and in removed gross specimen," Ultrasound Funct. Diag., no. 4, pp. 25 - 30, 2014.)

11. В. В. Митьков, С. А. Хуако, Э. Р. Ампилогова, М. Д. Митькова, “Оценка воспроизводимости результатов количественной ультразвуковой эластографии," Ультразвуковая и функциональная диагностика, но. 2, стр. 115 - 121, 2011. (V. V. Mit'kov, S. A. Huako, E. R. Ampilogova, M. D. Mit'kova, "Reproducibility evaluation of quantitative ultrasonic elastography results," Ultrasound Funct. Diag., no. 2, pp. 115 - 121, 2011.)

12. В. В. Митьков, С.А. Хуако, С.Э. Саркисов, М. Д. Митькова, "Количественная оценка эластичности миометрия в норме," Ультразвуковая и функциональная диагностика, но. 5, стр. 14 - 19, 2011. (V. V. Mit'kov, S. A. Huako, S. E. Sarkisov, M. D. Mit'kova, "Quantification of myometrium elasticity in the norm," Ultrasound Funct. Diag., no. 5, pp. 14 - 19, 2011.)

13. В. В. Митьков, С.А. Хуако, С.Э. Саркисов, М.Д. Митькова, "Возможности эластографии и эластометрии сдвиговой волны в диагностике аденомиоза," Ультразвуковая и функциональная диагностика, но. 6, стр. 22 - 28, 2011. (V. V. Mit'kov, S. A. Huako, S. E. Sarkisov, M. D. Mit'kova, "Opportunities of elastography and shear wave elastometry in diagnosis of adenomyosis," Ultrasound Funct. Diag., no. 6, pp. $22-28$, 2011.)

14. В. В. Митьков, С. А. Хуако, С. Е. Цыганов, Т. А. Кириллова, М. Д. Митькова, “Сравнительный анализ данных эластографии сдвиговой волной и результатов морфологического исследования тела матки (предварительные результаты), Ультразвуковая и функииональная диагностика, но. 5, стр. 99 - 114, 2013. (V. V. Mit'kov, S. A. Huako, S. E. Cyganov, T. A. Kirillova, M. D. Mit'kova, "Comparative analysis of shear wave elastography data and uterine body morphological study results (preliminary results)," Ultrasound Funct. Diag., no. 5, pp. 99 - 114, 2013.)

15. L. C. Carlson et al., "Estimation of shear wave speed in the human uterine cervix," Ultrasound Obstet. Gynecol., vol. 43, no. 4, pp. 452 - 458, Apr. 2014.

DOI: 10.1002/uog.12555

PMid: 23836486

PMCid: PMC 3894258

16. E. Hernandez-Andrade et al., "Effect of depth on shearwave elastography estimated in the internal and external cervical os during pregnancy," J. Perinat. Med., vol. 42, no. 5, pp. 549 - 557, Sep. 2014.

DOI: $10.1515 / \mathrm{jpm}-2014-0073$

PMid: 25029081

PMCid: PMC4183447 